\title{
A case of right sided cardiosplenic heterotaxy syndrome
}

\author{
*M B K C Dayasiri ${ }^{1}$, C T Perera ${ }^{2}$, W Bandara ${ }^{2}$, O J C Ranasinghe
}

Sri Lanka Journal of Child Health, 2016: 45(1): 46-47

DOI: http://dx.doi.org/10.4038/sljch.v45i1.8086

(Key words; Cardiosplenic heterotaxy syndrome)

\section{Introduction}

Heterotaxy is said to exist when the internal thoracoabdominal organs demonstrate abnormal arrangement across the left-right axis of the body ${ }^{1}$. It is categorized into asplenia and polysplenia syndrome variants $^{1}$. Asplenia syndrome is characterized by complex congenital heart defects, asplenia and abdominal heterotaxy ${ }^{1}$. Evidence with regard to the incidence of isomerism is sparse ${ }^{1}$. However, recent studies show that it is commoner in Asians compared to Western populations ${ }^{2}$. Most cases of right isomerism are recognized in early infancy because of the presence of severe forms of complex cyanotic heart disease ${ }^{1}$. Infants with right isomerism invariably have obstruction of the pulmonary outflow tract, as well as common mixing at atria and ventricles, and pulmonary atresia is present in $67 \%$ of cases $^{3}$. Here we report an unusual and relatively late presentation of an infant with right sided cardiosplenic heterotaxy syndrome associated with severe cyanotic congenital heart disease.

\section{Case report}

A five month old girl was brought to the paediatric casualty by her non consanguineous parents following a history of sudden onset respiratory distress while breast feeding. She had been well, apart from mild discomfort in the erect position while burping the child. She was born uncomplicated at term, weighing $2.16 \mathrm{~kg}$ and was discharged on day 2 with normal newborn examination findings.

${ }^{1}$ Registrar in Paediatrics, ${ }^{2}$ Acting Paediatrician, University Paediatric Unit, Anuradhapura Teaching Hospital, Sri Lanka.

*Correspondence: mbkcdayasiri@gmail.com (Received on 11 September 2014: Accepted after revision on 24 October 2014)

The authors declare that there are no conflicts of interest

Personal funding was used for this project.

Open Access Article published under the Creative Commons Attribution CC-BY (cC)

At presentation, child was gasping with severe respiratory distress without central or peripheral cyanosis. Capillary refill time was 4 seconds and oxygen saturation in the probe held in right hand was $60 \%$. Venous blood gas showed severe metabolic acidosis. She was given ventilation breaths with volume resuscitation and later transferred to the paediatric intensive care unit for ventilator care. Despite timely intervention, oxygen saturation did not pick up above $70 \%$. Clinically there was no murmur. Liver was not palpable in the right hypochondrium. Lump measuring $3 \mathrm{~cm}$ was palpable below the left costal margin. Electrocardiogram showed right axis deviation with right ventricular hypertrophy and chest roentgenogram showed pulmonary oligaemia and a hiatal hernia. Roentgenogram showed liver in the left hypochondrium with coiling of bowel loops in the right hypochondrium (Figure 1).

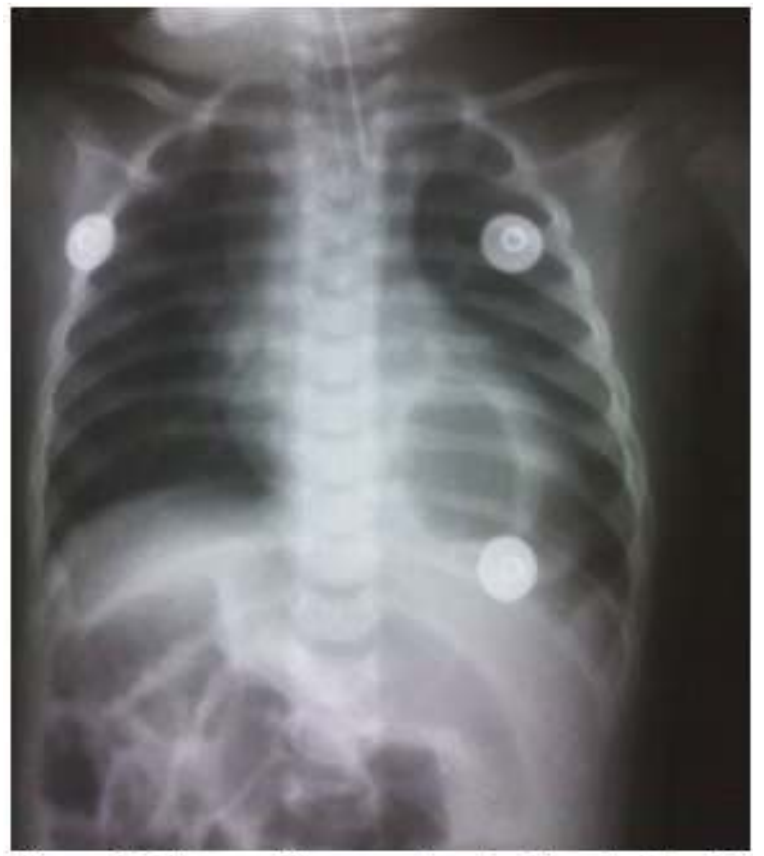

Figure 1: $X$-ray abdomen showing liver in the left hypochondrium \& bowel loops in the right hypochondrium

Ultrasound scan of abdomen showed asplenia and left sided liver with midline gallbladder. Sliding hiatal 
hernia was seen with poorly visualized stomach. However, nasogastric tube was seen to be passing to right hypochondrial region through the epigastrium. Ultrasound imaging of the brain was normal. Echocardiogram revealed complex heart disease comprising atrioventricular canal defect, partial anomalous pulmonary venous drainage, double outlet right ventricle with pulmonary atresia and duct dependant pulmonary circulation. The left ventricle was rudimentary and was suitable only for a univentricular repair.

\section{Discussion}

The prognosis of children with complex cardiac lesions and asplenia is poor. Prolonged functional survival is very uncommon in this variant, with death usually caused by congestive heart failure or severe infection ${ }^{4}$. The one-year mortality is greater than $85 \%$ for patients with asplenia ${ }^{5}$. Heterotaxy syndrome with polysplenia has been reported in adults ${ }^{6}$. However, asplenia syndrome invariably presents in early infancy with heart failure, septicaemia and cyanosis and delayed presentations are exceedingly rare ${ }^{4}$.

In this case report, a murmur was not present at birth and child remained well without having any signs of heart failure or chest infections, central or peripheral cyanosis until he developed sudden onset, severe metabolic acidosis with respiratory distress leading to initial suspicion with regard to severe cyanotic congenital heart disease. This highlights the importance of pulse oximetry screening of newborns before discharge from the postnatal ward, irrespective of how healthy or sick they are, so that clinically hidden duct dependant circulations are detected at an early opportunity ${ }^{7}$.

\section{Acknowledgements}

The authors acknowledge Dr. Shehan Perera, Consultant Paediatric Cardiologist, Lady Ridgeway Hospital, Colombo, Dr. Sanjeewa Rajapakse, Consultant Cardiologist, Teaching Hospital Anuradhapura and Dr. Priyanthi Rathnayake, Consultant Radiologist, Teaching Hospital Anuradhapura for their valuable opinions in evaluating cardiac and intra-abdominal abnormalities of this child.

\section{References}

1. Kim SJ. Heterotaxy syndrome. Korean Circulation Journal 2011; 41(5):227-32. http://dx.doi.org/10.4070/kcj.2011.41.5.227 PMid: 21731561 PMCid: PMC3116098
2. Kim SJ, Kim WH, Lim HG, Lee JY. Outcome of 200 patients after an extracardiac Fontan procedure. Journal of Thoracic and Cardiovascular Surgery 2008; 136(1):108-16. http://dx.doi.org/10.1016/j.jtcvs.2007.12.032 PMid: 18603062

3. De Tommasi S, Daliento L, Ho SY, Macartney FJ, Anderson RH. Analysis of atrioventricular junction, ventricular mass, and ventriculoarterial junction in 43 specimens with atrial isomerism. British Heart Journal 1981; 45(3):236-47.

http://dx.doi.org/10.1136/hrt.45.3.236

PMid: 7470338 PMCid: PMC482520

4. Wolfe MW, Vacek JL, Kinard RE, Bailey CG. Prolonged and functional survival with the asplenia syndrome. American Journal of Medicine 1986; 81(6):1089-91. http://dx.doi.org/10.1016/00029343(86)9041 $5-8$

5. Bartz PJ, Driscoll DJ, Dearani JA, Puga FJ, Danielson GK, O'Leary PW, et al. Early and late results of the modified Fontan operation for heterotaxy syndrome: 30 years of experience in 142 patients. Journal of the American College of Cardiology 2006; 48(11):2301-5.

http://dx.doi.org/10.1016/j.jacc.2006.07.053 PMid: 17161263

6. Prieto Martínez C, Vila Costas JJ, García Sanchotena JL, Borda Celaya F. Heterotaxy syndrome (polysplenia) in an adult. Radiologia 2007; 49(3):211-4. http://dx.doi.org/10.1016/S00338338(07)73 753-0

7. de-Wahl Granelli A, Wennergren M, Sandberg K, Mellander M, Bejlum C, Inganäs Let al. Impact of pulse oximetry screening on the detection of duct dependent congenital heart disease: a Swedish prospective screening study in 39,821 newborns. British Medical Journal 2009; 338:a3037.

http://dx.doi.org/10.1136/bmj.a3037

PMid: 19131383 PMCid: PMC2627280 